\title{
Kinerja Simpang Tak Bersinyal Sultan Alauddin dan Monumen Emmy Saelan di Era New Normal
}

\author{
Winarno Saelan*1, Rais Rachman ${ }^{* 2}$, Sufiati Bestari ${ }^{* 3}$ \\ *1 Mahasiswa Program Studi Teknik Sipil, Universitas Kristen Indonesia Paulus, Makassar \\ Email winarnosaelan@gmail.com \\ *2 Dosen Program Studi Teknik Sipil, Universitas Kristen Indonesia Paulus, Makassar \\ Email rais.rachman@gmail.com \\ *3 Dosen Program Studi Teknik Sipil, Universitas Kristen Indonesia Paulus, Makassar \\ Email sufiati.bestari@gmail.com
}

\begin{abstract}
ABSTRAK
Arus lalu lintas puncak, perhitungan kapasitas simpang, dan derajat kejenuhan simpang tak bersinyal mengacu pada Manual Kapasitas Jalan Indonesia 1997. Penelitian ini bertujuan untuk mengetahui derajat kejenuhan simpang tak bersinyal Jalan Sultan Alauddin dan Monumen Emmy Saelan, Makassar pada masa new normal. Survei lalu lintas pada Senin dan Kamis mewakili hari kerja, survei pada sabtu mewakili hari libur. Kendaraan yang dicacah yaitu kendaraan ringan, kendaraan berat, sepeda motor, dan kendaraan tak bermotor. Proporsi kendaraan tak bermotor dan kendaraan bermotor diperhitungkan pada analisis kapasitas simpang. Arus lalu lintas puncak terjadi pada sore hari yang diwakili hari kerja, yaitu: $Q=6917,3 \mathrm{smp} / \mathrm{jam}$, kapasitas simpang $(C)=4350,18 \mathrm{smp} / \mathrm{jam}$, derajat kejenuhan $(\mathrm{DS})=1,59$.
\end{abstract}

Kata Kunci : derajat kejenuhan, simpang tak bersinyal, era baru, MKJI 1997

\begin{abstract}
The peak of traffic flow, the calculation of the intersection capacity, and the degree of saturation of the unsigned intersection referring to the Indonesian Highway Capacity Manual, 1997. This study aims to determine the degree of saturation of the unsigned intersection of Sultan Alauddin and Monumen Emmy Saelan Street, Makassar during the new normal period. The traffic survey on Monday and Thursday Indicated weekdays, the survey on Saturday indicated holidays. The vehicles enumerated were light vehicles, heavy vehicles, motorcycles and unmotorized. The proportion of unmotorized and motorcycles were calculated in the analysis of intersection capacity. The Peak of traffic flow occurred in the afternoon which indicated the working days, the results are as follows, $Q=6917.3$ pcu/hour, intersection capacity $(C)=4350,18$ pcu/hour, degree of saturation (DS) $=1.59$.
\end{abstract}

Keywords: degree of saturation, unsigned intersections, new normal, IHCM 1997

\section{PENDAHULUAN}

Persimpangan merupakan area bertemunya arus lalu lintas kendaraan dari berbagai arah yang menimbulkan konflik lalu lintas sehingga berpotensi menyebabkan kemacetan. Pada simpang tiga tak bersinyal Jalan Sultan Alauddin dan Jalan Monumen Emmy Saelan merupakan area yang kerap mengalami konflik lalu lintas. Jalan Sultan Alauddin merupakan jalan utama penghubung Kota Makassar dengan Kabupaten Gowa. Bagian hulu (upstream) ruas Jalan Monumen Emmy Saelan sebelum persimpangan merupakan kawasan perkantoran, perdagangan dan pemukiman penduduk sehingga memiliki arus lalu lintas yang kompleks dan tingkat pergerakan lalu lintas yang cukup tinggi.
Pandemi Covid-19 yang saat ini melanda secara global menyebabkan pemerintah baik daerah maupun pusat di setiap negara mengambil kebijakan untuk membatasi moblitas masyarakat guna menekan laju penyebaran wabah penyakit [1]. Tidak terkecuali di Kota Makassar, pemerintah daerah mengambil kebijakan untuk beberapa sektor pekerjaan dilakukan di rumah, termasuk untuk pembatasan sosial berskala besar dan era normal baru. Pergerakan lalu lintas baik di ruas maupun di simpang untuk era normal baru juga akan mengalami perubahan.

Persimpangan adalah daerah atau tempat dimana dua atau lebih jalan raya bertemu atau berpotongan, sedangkan pada garis besarnya persimpangan terbagi dalam dua bagian yaitu (1) persimpangan sebidang dan (2) persimpangan tak 
Paulus Civil Engineering Journal

E- Jurnal Teknik Sipil UKI-Paulus Makassar http://ojs.ukipaulus.ac.id/index.php/pcei
Volume 2 No.4, Desember 2020

ISSN Online : $x x x x-x x x x$ sebidang [2]. Pada tipe simpang tak bersinyal yang letak pendekatnya tak sebidang, sering dijumpai titiktitik konflik arus lalu lintas yang mengakibatkan kemacetan arus lalu lintas terutama pada saat hari kerja [3].

Menurut Manual Kapasitas Jalan Indonesia, 1997, jenis kendaraan dibagi menjadi empat [4], yaitu : (1) Kendaraan ringan (Light Vehicle, LV), yaitu kendaraan bermotor as dua dengan 4 roda dan jarak as 2,0 - 3,0 m. Kendaraan ringan meliputi: mobil penumpang, mikrobis, pick-up, dan truk kecil. (2) Kendaraan berat (Heavy Vehicle, HV), yaitu kendaraan bermotor dengan jarak as lebih dari 3,5 $\mathrm{m}$ biasanya beroda lebih dari 4. Kendaran berat meliputi: bus, truck dua as, truck kombinasi sesuai klasifikasi dari Bina Marga. (3) Sepeda motor (Motor Cycle, MC), yaitu untuk kendaraan bermotor dengan dua roda dan kendaraan tiga roda. (4) Kendaraan tak bermotor (Unmotorized, UM), yaitu kendaraan yang digerakkan oleh dua orang manusia. Kendaraan tak bermotor meliputi: sepeda, becak, kereta kuda dan kereta dorong. Dalam Manual Kapasitas Jalan Indonesia kendaraan tak bermotor tidak dianggap sebagai bagian dari arus lalu lintas tetapi sebagai unsur dari hambatan samping.

Penelitian sebelumnya tingkat pelayanan suatu jalan dipengaruhi oleh faktor hambatan samping yang dapat menimbulkan kemacetan lalu lintas [5], kinerja ruas dengan menggunakan separator dipengaruhi oleh panjang separator dan kecepatan jalinan [6], semakin lebar bukaan median menyebabkan peningkatan kepadatan, karena mempengaruhi volume kendaraan yang akan melakukan merging dan diverging [7], pada simpang bersinyal, semakin tinggi arus semakin meningkatkan nilai kapasitas, antrian, dan tundaan [8], rata-rata nilai derajat kejenuhan pada simpang tak sebidang di jalan Urip Sumohardjo dan Dr. Leimena, Makassar adalah lebih besar dari 0,75 [9], kinerja simpang bundaran Gladak Surakarta pada tahun 2011 memiliki derajat kejenuhan pada bagian jalinan adalah $0,01,0,03,0,11$, dan 0,14 [10], kinerja simpang tiga Kalitan memiliki nilai derajat kejenuhan pendekat utara, selatan, dan barat, masing-masing 0,52, 0,97, dan ,1,19 [11].

Tujuan dari penelitian ini adalah mengetahui arus lalu lintas pada simpang tak bersinyal pertigaan Sultan Alauddin dan Monumen Emmy Saelan pada masa new normal, mengetahui kapasitas simpang tak bersinyal pada pertigaan Sultan Alauddin dan Monumen Emmy Saelan pada masa new normal, mengetahui derajat kejenuhan pada simpang tak bersinyal pertigaan Sultan Alauddin dan Monumen Emmy Saelan pada masa new normal.

\section{METODE}

Lokasi penelitian berada di Kota Makassar yaitu pada simpang tak bersinyal pertigaan Jalan Sultan Alauddin dan Jalan Monumen Emmy Saelan. Lokasi penelitian dapat dilihat pada gambar 1 .

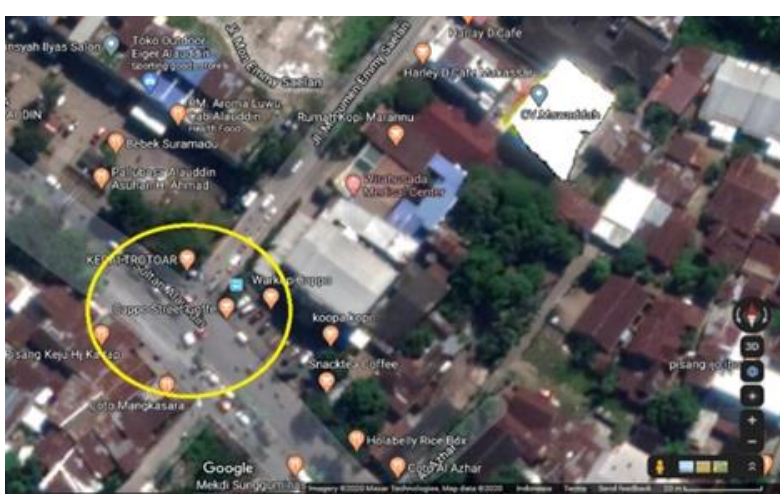

Gambar 1. Lokasi penelitian

Penelitian dilakukan tiga hari, yaitu pada hari Senin, Kamis dan Sabtu. Pemilihan hari ini diambil berdasarkan survei pendahuluan yang telah dilakukan ke lokasi. Dimana pemilihan hari Senin dan Kamis diambil untuk mewakili hari kerja, sedangkan pemilihan hari Sabtu diambil untuk mewakili hari libur. Penelitian ini dimulai pukul 06.00-09.00 WITA, pukul 11.00-14.00 WITA, dan pukul 16.00-19.00 WITA.

Alat yang digunakan untuk survey yaitu Stop watch, Hand tally counter, kamera, meteran, dan alat tulis.

Dalam penelitian ini digunakan interval waktu pengamatan 15 menit dengan mencatat setiap pergerakan di masing-masing pendekat untuk setiap jenis kendaraan.

\section{Kapasitas Simpang (C)}

Kapasitas total untuk seluruh pendekat simpang adalah hasil perkalian antara kapasitas dasar (Co) yaitu kapasitas pada kondisi tertentu (ideal) dan faktor-faktor penyesuaian (F) dengan memperhitungkan pengaruh kondisi lapangan terhadap kapasitas. Rumusan kapasitas simpang menurut Manual Kapasitas Jalan Indonesia (Departemen Pekerjaan Umum Direktorat Jenderal Bina Marga, 1997) dihitung dengan Persamaan 1:

$\mathrm{C}=\mathrm{C}_{\mathrm{O}} \times \mathrm{F}_{\mathrm{W}} \times \mathrm{F}_{\mathrm{M}} \times \mathrm{F}_{\mathrm{CS}} \times \mathrm{F}_{\mathrm{RSU}} \times \mathrm{F}_{\mathrm{LT}} \times \mathrm{F}_{\mathrm{RT}} \times \mathrm{F}_{\mathrm{Ml}}$

Dimana:

Co $\quad$ : kapasitas dasar (smp/jam)

Fw : faktor koreksi pengaruh lebar jalur efektif

$F_{M} \quad$ : faktor koreksi pengaruh lebar median

FCs : faktor koreksi pengaruh ukuran kota 
FRSU :faktor penyesuaian tipe lingkungan, hambatan samping, dan kendaraan tak bermotor

$F_{L T} \quad$ : faktor koreksi pengaruh belok kiri

$\mathrm{F}_{\mathrm{RT}}$ : faktor koreksi pengaruh belok kanan

$\mathrm{F}_{\mathrm{MI}}$ : faktor koreksi jalan minor

\section{Derajat kejenuhan}

Derajat kejenuhan (DS) merupakan rasio arus lalu lintas (smp/jam) terhadap kapasitas (smp/jam). Derajat kejenuhan dapat dihitung dengan Persamaan 2:

$\mathrm{DS}=\frac{\mathrm{Q}_{\mathrm{TOT}}}{\mathrm{C}}$

Dimana:

$\begin{array}{ll}\text { DS } & : \text { derajat kejenuhan } \\ \text { Qtot } & : \text { jumlah arus total (smp/jam) } \\ \text { C } & : \text { kapasitas (smp/jam) }\end{array}$

\section{HASIL DAN PEMBAHASAN}

\section{Fluktuasi arus}

Pada hari pengamatan sabtu 8 Agustus 2020, pada pendekat $A$ memiliki variasi arus per 15 menitan dengan arus puncak $154,8 \mathrm{smp} / 15$ menit terjadi pada pukul 13.15-13.30 WITA, terjadi arus puncak $739,8 \mathrm{smp} / 15$ menit di pendekat $B$ pada pukul 08.30-08.45 WITA, arus puncak sebesar 979,5 smp/15 menit pada pukul 17.00-17.15 di pendekat $D$. Fluktuasi arus hari pengamatan sabtu 8 Agustus 2020 masing-masing pendekat dapat dilihat pada Gambar 2,3, dan 4.

Pada hari pengamatan senin 10 Agustus 2020, pada pendekat $A$ memiliki variasi arus per 15 menitan dengan arus puncak $979,5 \mathrm{smp} / 15$ menit terjadi pada pukul 17.00-17.15 WITA, terjadi arus puncak 943,9 smp/15 menit di pendekat B pada pukul 07.45-08.00 WITA, arus puncak sebesar 995,1 smp/15 menit pada pukul 17.00-17.15 di pendekat $D$. Fluktuasi arus hari pengamatan senin 10 Agustus 2020 masing-masing

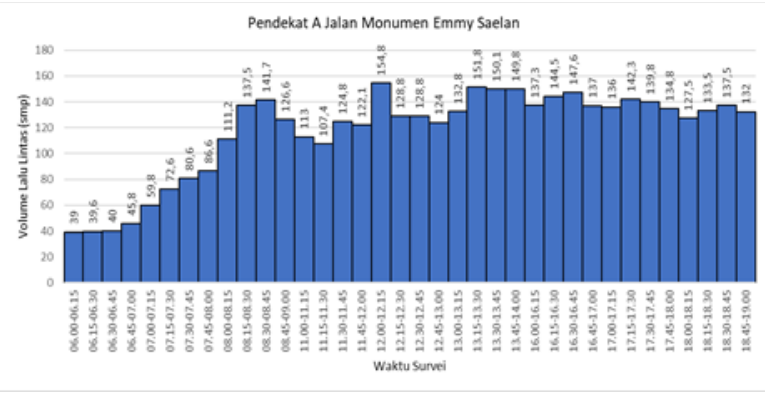

Gambar 2. Fluktuasi arus pendekat A

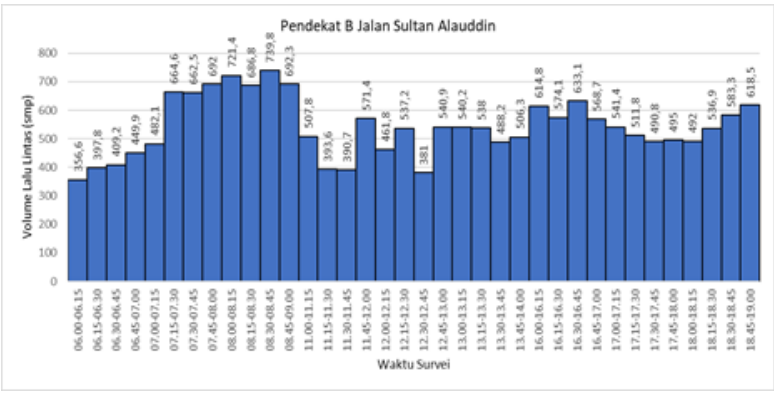

Gambar 3. Fluktuasi arus pendekat B

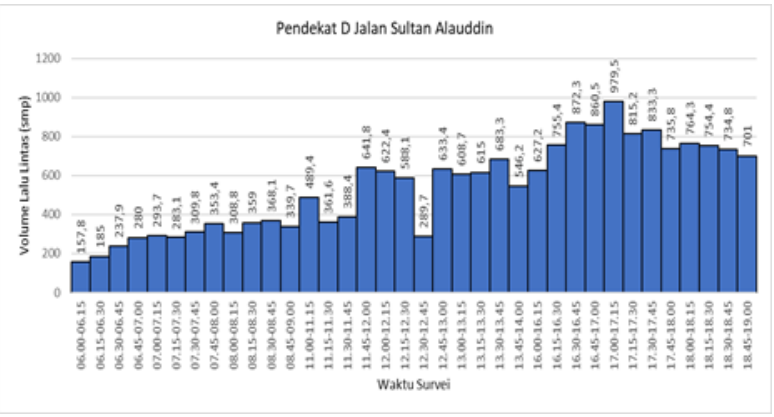

Gambar 4. Fluktuasi arus pendekat D

pendekat dapat dilihat pada Gambar 5,6, dan 7 .

Pada hari pengamatan kamis 13 Agustus 2020, pada pendekat $A$ memiliki variasi arus per 15 menitan dengan arus puncak $145,1 \mathrm{smp} / 15$ menit terjadi pada pukul 17.30-17.45 WITA, terjadi arus puncak $876,7 \mathrm{smp} / 15$ menit di pendekat B pada pukul 07.45-08.00 WITA, arus puncak sebesar 934,7 smp/15 menit pada pukul 16.30-16.45 di pendekat $D$. Fluktuasi arus hari pengamatan senin 10 Agustus 2020 masing-masing pendekat dapat dilihat pada Gambar 8,9, dan 10.

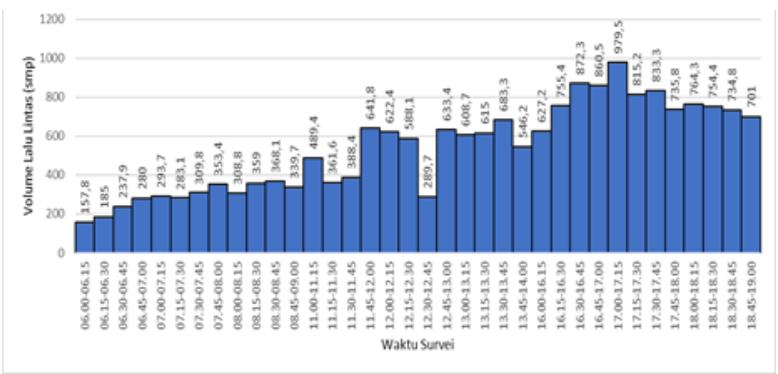

Gambar 5. Fluktuasi arus pendekat A 


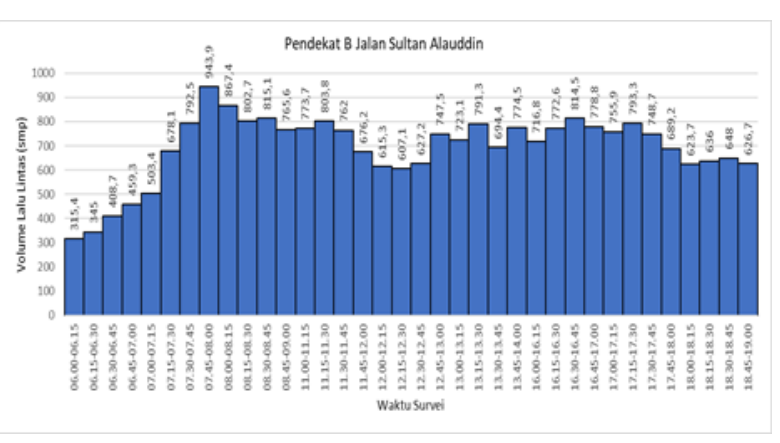

Gambar 6. Fluktuasi arus pendekat B

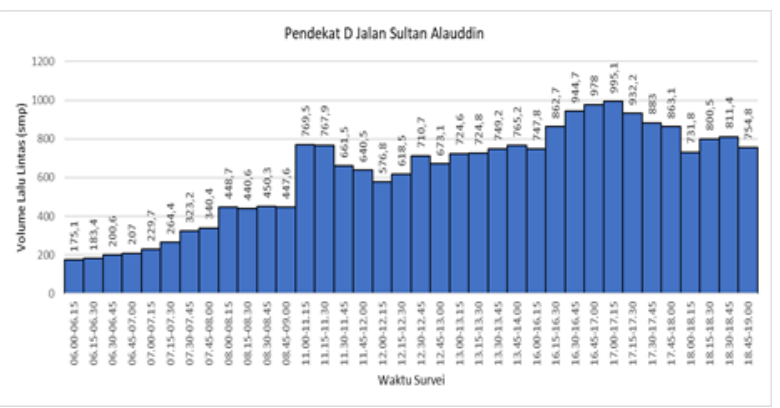

Gambar 7. Fluktuasi arus pendekat D

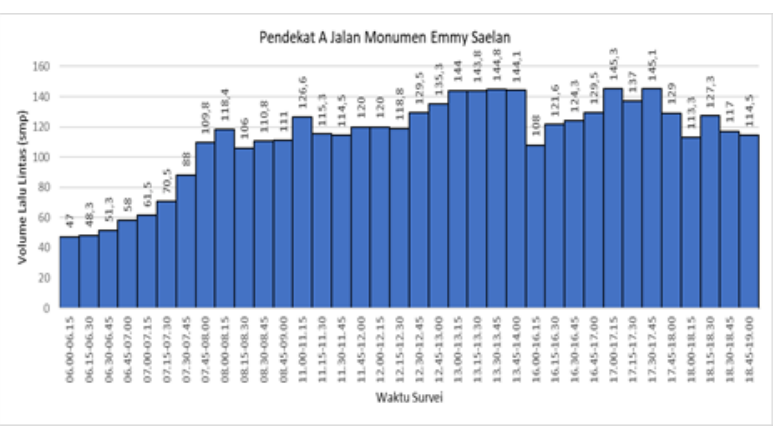

Gambar 8. Fluktuasi arus pendekat A

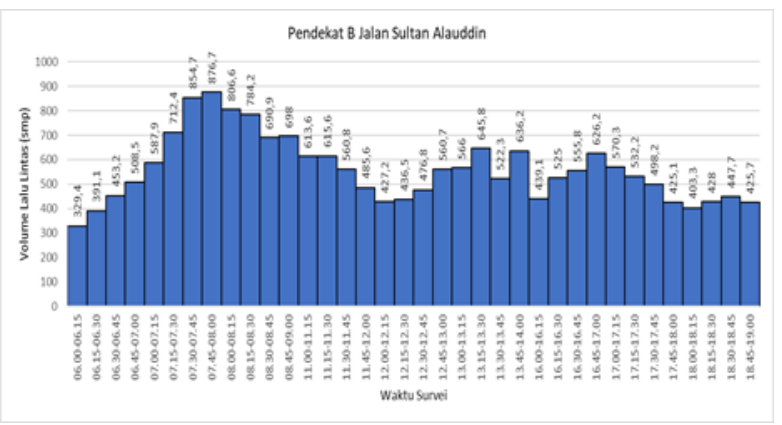

Gambar 9. Fluktuasi arus pendekat B

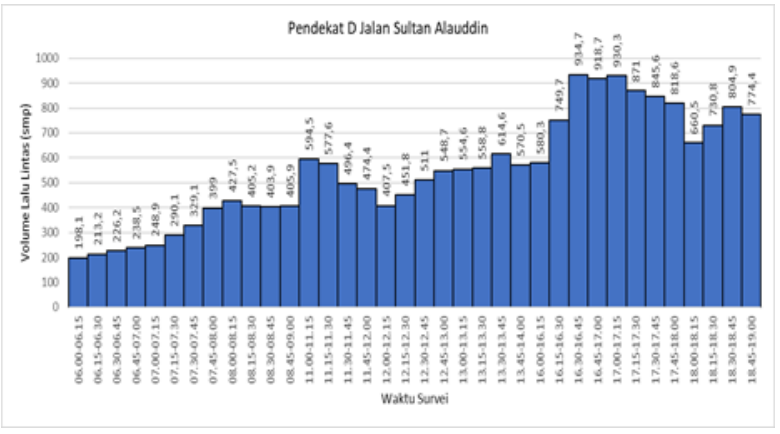

Gambar 10. Fluktuasi arus pendekat D

\section{Arus puncak setiap pendekat}

Dari hasil pengamatan dan pencacahan lalu lintas di lokasi, diperoleh pada hari sabtu, 8 Agustus 2020 pada pendekat Sultan Alauddin B (ke arah Makassar), Sultan Alauddin D (ke arah Gowa), dan Monumen Emmy Saelen A masing-masing memiliki arus puncak pagi sebesar 2776,8 smp/jam, 1383,2 smp/jam, dan 517 smp/jam, sedangkan untuk sore hari masing-masing pendekat B, D, dan A, yaitu 2295,9 smp/jam, $3488,64 \mathrm{smp} / \mathrm{jam}$, dan 564,8 smp/jam. Arus puncak pagi pada hari senin 10 Agustus 2020 untuk pendekat $B, D$, dan A adalah 3355,76 smp/jam, 1787,2 smp/jam, dan 509,68 smp/jam, sedangkan arus puncak pada sore hari 3132,08 smp/jam (pendekat B), 3786,4 smp/jam (pendekat D), dan 646,7 smp/jam (pendekat A). Hari kamis 13 Agustus 2020, arus puncak pagi hari untuk masing-masing pendekat $\mathrm{B}, \mathrm{D}$, dan $\mathrm{A}$ adalah 3322,2 smp/jam, 1633,2 smp/jam, dan 444,8 smp/jam, untuk sore hari masing-masing 2247,6 smp/jam, 3545,93 smp/jam, dan 535,76 smp/jam. Pergerakan ke arah Kota Makassar paling banyak terjadi pada hari kerja dan libur (senin, kamis, dan sabtu), sedangkan untuk arah sebaliknya (ke arah Gowa) pergerakan terbanyak pada sore hari. Arus lalu lintas untuk setiap pendekat dapat dilihat pada Tabel 1. Dalam komposisi jenis kendaraan di setiap pendekat, sepeda motor merupakan jenis kendaraan yang mendominasi, diikuti dengan kendaraan ringan (light vehicle), kendaraan berat (heavy vehicle), dan kendaraan tak bermotor (unmotorized vehicle). Proporsi sepeda motor (motor cycle) untuk pergerakan di pendekat $A$ $70,3 \%$, diikuti LV, UM, dan HV, masing-masing $28.4 \%, 0,8 \%$, dan $0,5 \%$. Proporsi masing-masing jenis kendaraan di pendekat $B, 66.6 \%(\mathrm{MC}), 31.3 \%$ (LV), $1,3 \%(\mathrm{HV})$, dan 0,9\% (UM). Pendekat A memiliki proporsi berdasarkan jenis kendaraan sepeda motor, kendaraan ringan, kendaraan berat, dan kendaraan tak bermotor, masing-masing 
$69,3 \%, 29,5 \%, 0,7 \%$, dan $0,5 \%$. Arus lalu lintas setiap pergerakan di masing-masing pendekat disajikan pada Tabel 2.

Gambar 11 memperlihatkan konflik arus lalu lintas yang terjadi pada simpang tak bersinyal Jalan
Sultan Alauddin dan Jalan Monumen Emmy Saelan. Pergerakan arus lalu lintas berbalik arah (u-turn) merupakan pergerakan dua kali belok kanan beruntun yang diperhitungkan sebagai belok kanan dalam Tabel 1 dan Tabel 2 .

Tabel 1. Arus lalu lintas setiap pendekat

\begin{tabular}{cccc}
\hline \multirow{2}{*}{ Waktu Survei } & Pendekat & \multicolumn{2}{c}{ Arus Lalu Lintas Puncak (smp/jam) } \\
\cline { 3 - 4 } & & Pagi & Sore \\
\hline \multirow{3}{*}{ Sabtu, 08 Agustus 2020 } & A & 517 & 564,8 \\
& B & 2776,8 & 2295,9 \\
Senin, 10 Agustus 2020 & D & 1383,2 & 3488,64 \\
& A & 509,68 & 646,667 \\
Kamis, 13 Agustus 2020 & B & 3355,76 & 3132,08 \\
& D & 1787,2 & 3786,4 \\
& A & 444,8 & 535,76 \\
& B & 3322,2 & 2247,6 \\
& D & 1633,2 & 3545,93 \\
\hline
\end{tabular}

Tabel 2. Arus lalu lintas setiap pergerakan di pendekat

\begin{tabular}{|c|c|c|c|c|c|c|c|}
\hline \multirow{2}{*}{$\begin{array}{l}\text { Jenis } \\
\text { Kendaraan } \\
\text { (kend/jam) }\end{array}$} & \multicolumn{2}{|c|}{$\begin{array}{c}\text { Jalan Monumen Emmy } \\
\text { Saelan } \\
(\text { Pendekat A) }\end{array}$} & \multicolumn{2}{|c|}{$\begin{array}{l}\text { Jalan Sultan Alauddin } \\
\text { (Pendekat B) }\end{array}$} & \multicolumn{3}{|c|}{$\begin{array}{l}\text { Jalan Sultan Alauddin } \\
\quad \text { (Pendekat D) }\end{array}$} \\
\hline & $\begin{array}{c}\text { Belok } \\
\text { Kiri (LT) }\end{array}$ & $\begin{array}{c}\text { Belok Kanan } \\
\text { (RT) }\end{array}$ & $\begin{array}{l}\text { Lurus } \\
\text { (ST) }\end{array}$ & $\begin{array}{c}\text { Belok } \\
\text { Kanan } \\
(\mathrm{RT})\end{array}$ & $\begin{array}{c}\text { Belok } \\
\text { Kiri } \\
\text { (LT) }\end{array}$ & $\begin{array}{l}\text { Lurus } \\
\text { (ST) }\end{array}$ & $\begin{array}{l}\text { Belok Kanan } \\
\qquad(\mathrm{RT})\end{array}$ \\
\hline LV & 139 & 126 & 1076 & 185 & 135 & 1374 & 151 \\
\hline HV & 4 & 1 & 48 & 6 & 2 & 32 & 3 \\
\hline $\mathrm{MC}$ & 325 & 331 & 2075 & 562 & 338 & 3316 & 266 \\
\hline UM & 3 & 4 & 33 & 2 & 4 & 27 & 1 \\
\hline
\end{tabular}

3. Kapasitas Simpang

Kapasitas simpang menggunakan persamaan 1 .
Co $=3200$
$F_{W}=1,075$
$F_{M}=1,05$
$F_{C S}=1,00$
$\mathrm{F}_{\mathrm{RSU}}=0,94$

$F_{L T}=0,983$

$\mathrm{F}_{\mathrm{RT}}=0,950$

$\mathrm{F}_{\mathrm{MI}}=1,327$

Sehingga:

C $=4350,18 \mathrm{smp} / \mathrm{jam}$

Derajat Kejenuhan

Derajat kejenuhan (DS) dihitung dengan menggunakan persamaan 2 . 


$$
\begin{aligned}
& \text { Qтот }=6917,3 \mathrm{smp} / \mathrm{jam} \\
& \mathrm{C}=4350,18 \mathrm{smp} / \mathrm{jam}
\end{aligned}
$$

Sehingga:

$$
\begin{aligned}
\text { DS } & =\frac{6917,3}{4350,18} \\
& =1,59(\text { derajat kejenuhan yang terjadi }>1)
\end{aligned}
$$

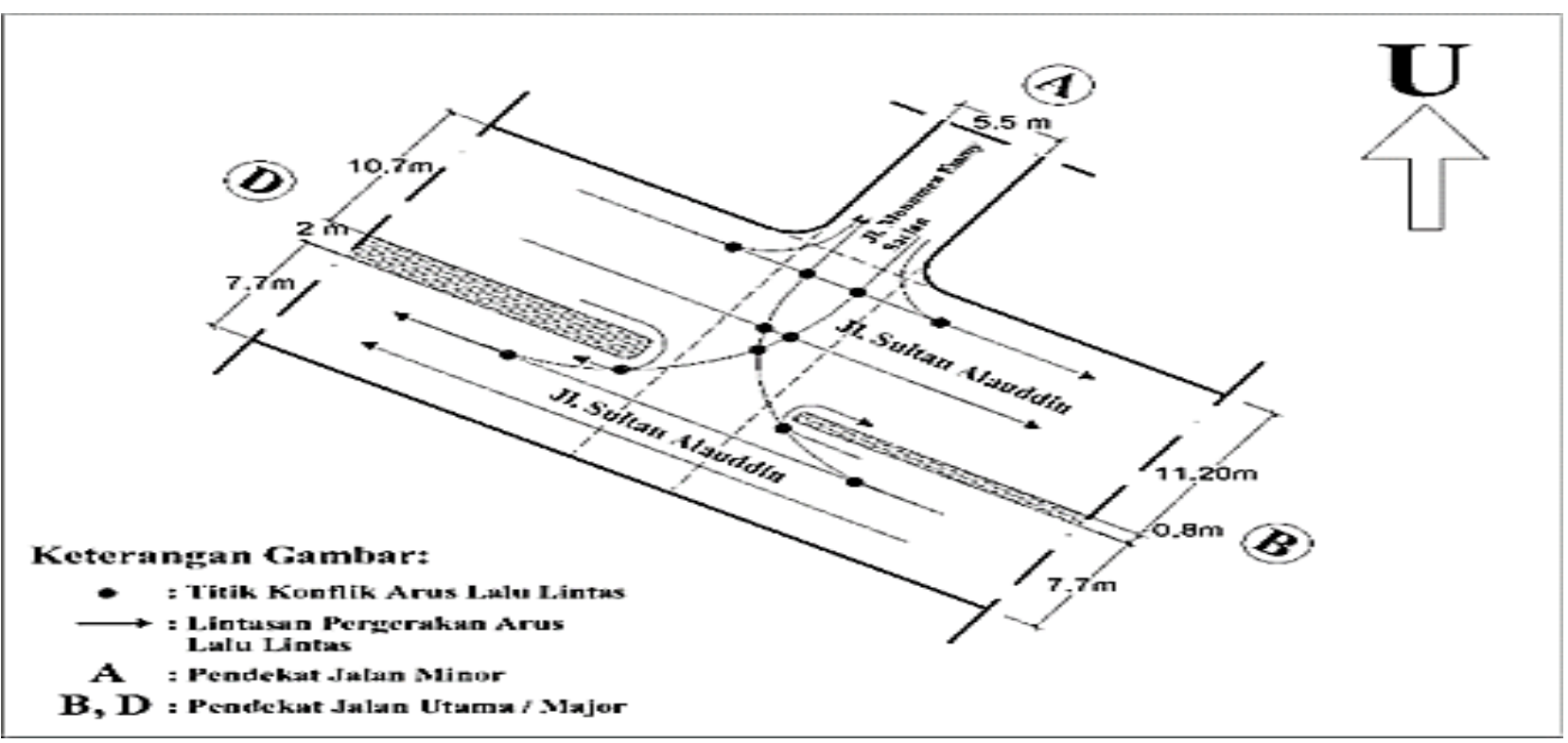

Gambar 11. Konflik arus lintas di simpang tak bersinyal

\section{Derajat Kejenuhan}

Derajat kejenuhan (DS) dihitung dengan menggunakan persamaan 2 .

$$
\begin{aligned}
& \text { Qтот }=6917,3 \mathrm{smp} / \mathrm{jam} \\
& \mathrm{C}=4350,18 \mathrm{smp} / \mathrm{jam}
\end{aligned}
$$

Sehingga:

$$
\begin{aligned}
\text { DS } & =\frac{6917,3}{4350,18} \\
& =1,59 \text { (derajat kejenuhan yang terjadi }>1 \text { ) }
\end{aligned}
$$

Idealnya nilai $\mathrm{DS} \leq 1$, jika $\mathrm{DS}=1$ berarti arus lalu lintas total dari semua pendekat sama besar dengan kapasitas simpang tak bersinyal dianalisis dengan asumsi lebar pendekat selebar yang diukur dari marka tepi ke marka tepi. Kendaraan datang dan melalui pendekat secara disiplin berurutan.

Fakta yang terjadi pada pendekat khususnya sepeda motor, walaupun datang pada posisi terakhir akan menyelinap maju diantara celah kendaraan mengisi ruang kosong didepan. Perilaku pengendara sepeda motor dan pengendara mobil dalam bermanuver (memanfaatkan ruang kosong) di mulut simpang menyebabkan kapasitas aktual persimpangan lebih besar dari kapasitas yang dihitung dari Persamaan 12, yaitu $C=4350,18 \mathrm{smp} / \mathrm{jam}$. Selain hal tersebut, penggunaan persamaan 12 akan menyebabkan kesalahan perkiraan kapasitas yang biasanya kurang dari $\pm 20 \%$ (Departemen Pekerjaan Umum Direktorat Jenderal Bina Marga, 1997).

Nilai $\mathrm{DS}=1,59$ yang dihasilkan dari perhitungan data arus lalu lintas hari kerja dan kapasitas simpang Jalan Sultan Alauddin dan Jalan Monumen Emmy Saelan berarti arus lalu lintas yang melintasi persimpangan melampaui kapasitas persimpangan sebesar $6917,3 \mathrm{smp} / \mathrm{jam}$. Jalan minor Monumen Emmy Saelan jauh lebih sempit dari pada Jalan utama Sultan Alauddin sehingga arus belok kanan dari Jalan Monumen Emmy Saelan tertumpuk untuk memotong arus lurus dari Pendekat D Jalan Sultan Alauddin, berkonflik dengan arus belok kanan dari Pendekat B Jalan Sultan Alauddin. Arus belok kanan dari Pendekat $B$ juga terhambat, berkonflik dengan arus belok kanan dari Pendekat $A$ dan berkonflik lagi untuk memotong arus lurus dari Pendekat $D$ sebelum bergabung dengan arus belok kiri Pendekat D keluar persimpangan ke Jalan Monumen Emmy Saelan.

Untuk meningkatkan kenyamanan dan keselamatan pengendara pada persimpangan Jalan Sultan Alauddin dan Jalan Monumen Emmy Saelan maka perlu dipasang lampu sinyal untuk 
mengatur lalu lintas yang akan memasuki area persimpangan. Karena DS $>1$ serta mengingat perilaku pengemudi di Indonesia yang hanya taat pada lampu sinyal lalu lintas, maka pengaturan yang memberikan prioritas lebih dahulu bagi kendaraan yang berasal dari jalan utama tidak dianjurkan. Pertimbangan lain untuk mengubah ke persimpangan tak bersinyal adalah jika efek kemacetan sudah menimbulkan kecelakaan.

\section{KESIMPULAN}

Arus lalu lintas puncak simpang tak bersinyal Jalan Sultan Alauddin dan Jalan Monumen Emmy Saelan pada masa new normal terjadi pada sore hari yang diwakili data survei hari kerja sebesar $6917,3 \mathrm{smp} / \mathrm{jam}$.

Kapasitas simpang tak bersinyal Jalan Sultan Alauddin dan Jalan Monumen Emmy Saelan sebesar 4350,18 smp/jam.

Derajat kejenuhan pada simpang tak bersinyal Jalan Sultan Alauddin dan Jalan Monumen Emmy Saelan sebesar 1,59 yang berarti arus lalu lintas pada simpang tak bersinyal Jalan Sultan Alauddin dan Jalan Monumen Emmy Saelan sangat macet.

\section{DAFTAR PUSTAKA}

[1] R. Rachman, 2020, "Transportasi," dalam Dampak Pandemi Global Covid-19 dalam Multi Perspektif, Edisi Covid., Kota Makassar: Tohar Media, hlm. 17-32.

[2] J. Khisty C. dan B. K. Lall, 2005, Dasar Dasar Rekayasa Transportasi, Edisi Ketiga, vol. 1. Jakarta: Erlangga

[3] S. P. Warpani, 2002, Pengelolaan lalu lintas dan angkutan jalan. Bandung: Penerbit ITB

[4] Direktorat Bina Marga, 1997, "Manual Kapasitas Jalan Indonesia (MKJI)," Jakarta: Departemen Pekerjaan Umum
[5] R. Kristanti, R. Rachman, dan L. E. Radjawane, 2020, "Analisis Dampak Hambatan Samping Terhadap Tingkat Pelayanan Jalan Kota Makassar," Paulus Civ. Eng. J., vol. 2, no. 2, hlm. 85-91

[6] L. E. Radjawane, 2019, "Pengaruh Separator Terhadap Kinerja Lalu Lintas Di Jalan Perkotaan," REKAYASA SIPIL, vol. 13, no. 2, hlm. 139-146, 2019, doi: https://doi.org/10.21776/ub.rekayasasipil.20 19.013.02.9.

[7] L. E. Radjawane, 2020, "The Effect of Median Opening on Traffic Characteristics on The Arterial Street," dalam Proceeding The 3rd International Conference on Civil and Environmental Engineering (ICCEE), Bali, Indonesia, 2020, vol. 419, doi: 10.1088/1755-1315/419/1/012102.

[8] F. G. Kendek, R. Rachman, dan L. E. Radjawane, 2020, "Kinerja Simpang Bersinyal Jalan Abdullah Daeng Sirua Batua Raya - Taman Makam Pahlawan Kota Makassar," Paulus Civ. Eng. J., vol. 2, no. 1 , hlm. 23-30

[9] P. Y. Haryanto, N. Ali, dan M. Hustim, 2004, "Studi Kinerja Simpang Tak Bersinyal Yang Tidak Sebidang Di Kota Makassar: Studi Kasus Simpang Jalan Urip Sumoharjo-Jalan Leimena," J. Transp., vol. 4, no. 1, hlm. 7984

[10] Sumina, 2012, "Analisis Kapasitas Dan Karakteristik Parkir Kendaraan Di Lokasi Perbelanjaan" (Studi Kasus Surakarta Grand Mall Surakarta)," Tek. Sipil Dan Arsit., vol. 6, no. 10, hlm. 25-34

[11] A. Sumarsono, Prahartanto Fajar Sidiek, dan Djumari, 2017, "Kinerja Simpang Bersinyal dan Tak Bersinyal (Studi Kasus Simpang Bersinyal Gendengan dan Simpang Tak Bersinyal Jalan Dokter Moewardi - Jalan Kalitan, Surakarta)," MATRIKS Tek. SIPIL, vol. 5, no. 3, hlm. 2736 